\title{
ANALISIS PENENTUAN HARGA POKOK PRODUKSI DAN HARGA JUAL DENGAN MENGGUNAKAN METODE FULL COSTING PADA HOME INDUSTRYKHOIRIYAH DI TAMAN SARI, SINGARAJA.
}

\author{
Rina Hasyim \\ Program Studi Pendidikan Ekonomi, Fakultas Ekonomi \\ Universitas Pendidikan Ganesha \\ Singaraja, Indonesia \\ e-mail: rina.id968@gmail.com
}

\begin{abstract}
Abstrak
Tujuan dari penelitian ini adalah untuk menganalisis perbandingan antara perhitungan harga pokok produksi dan harga jual dengan menggunakan metode full costing yang dilakukan peneliti dengan perhitungan yang dilakukan oleh Home Industri Khoiriyah di Taman Sari, Singraja. Jenis penelitian ini merupakan penelitian deskriptif dengan menggunakan pendekatan kuantitatif. Lokasi penelitian ini dilaksanakan di home industry Khoiriyah yang beralamat di Jl. Pulau Selayar Gang VI No 14 Singaraja. Data dikumpulkan dengan menggunakan metode dokumentasi dan data dianalisis menggunakan metode full costing untuk menentukan harga pokok produksi dan harga jual. Hasil penelitian ini menunjukkan bahwa ada perbedaan, dalam perhitungan harga pokok produksi tempe dan tahu menurut taksiran perusahaan adalah $\mathrm{Rp} 9.223$ dan $\mathrm{Rp} 27.503,571$, sedangkan harga pokok produksi tempe dan tahu menurut metode full costing adalah Rp 9.610,473 dan Rp 28.618,228. Harga jual tempe dan tahu menurut perusahaan $\mathrm{Rp} 10.000$ dan Rp 40.000, sedangkan menurut cost plus pricing adalah Rp 11.724,733 untuk tempe dan $\mathrm{Rp} 34.914,235$ untuk tahu.
\end{abstract}

Kata kunci: Harga jual, Harga Pokok Produksi, Cost Plus Pricing, Full Costing

\begin{abstract}
The purpose of this study was to analyze whether there was a comparison between the calculation of cost of goods sold and selling price by using full costing method conducted by researchers with calculations made by Home Industry Khoiriyah in Taman Sari, Singraja. This research type was descriptive research by using quantitative approach. The location of this research was conducted in Khoiriyah home industry which was located at Jl. Pulau Selayar Gang VI No 14 Singaraja. Data collected using documentation method and data were analyzed using full costing method to determine cost of goods sold and selling price. The results of this study indicate that there are differences in the calculation of the cost of production of tempe and tofu according to the estimate of the company is $R p 9.223$ and $R p 27,503,571$, while the cost of production of tempe and tofu according to the full costing method is $\mathrm{Rp} 9.610,473$ and $\mathrm{Rp}$ $28,618,228$. The selling price of tempe and tofu according to the company Rp 10,000 and Rp 40,000, while according to cost plus pricing is $\mathrm{Rp} 11,724,733$ for tempe and $\mathrm{Rp} 34,914,235$ to tofu.
\end{abstract}

Keywords : Selling Price, Cost of Production, Cost Plus Pricing, Full costing 


\section{PENDAHULUAN}

Dalam suatu pabrik, untuk
memberikan penetapan harga produk merupakan hal yang sangatlah penting. Penetapan harga harus ditetapkan secara tepat, cermat, dan akurat. Mengingat manfaat informasi harga pokok produksi adalah untuk menentukan harga jual produk, pemantauan realisasi biaya produksi, perhitungan laba rugi periodik serta penentuan harga pokok persediaan produk jadi dan produk dalam proses yang akan disajikan dalam neraca (Mulyadi, 2010).

Menurut Supriyono (2000: 288) harga pokok produksi adalah jumlah biaya produksi yang melekat pada produk atau barang yang dihasilkan yang diukur dalam satuan mata uang dalam bentuk kas yang dibayarkan atau nilai jasa yang diserahkan atau dikorbankan, atau hutang yang timbul, atau tambahan modal yang diperlukan perusahaan dalam rangka proses produksi baik pada masa lalu maupun masa yang akan datang. Bastian (2008 : 40) mendefinisikan "Penentuan harga pokok adalah bagimana memperhitungkan biaya kepada suatu produk atau jasa, yang dapat dilakukan dengan cara memasukkan seluruh biaya produksi atau hanya memasukkan unsur biaya produksi variabel saja.

Mulyadi (1993 : 18) penentuan harga
pokok produksi adalah cara memperhitungkan unsur - unsur biaya ke dalam harga pokok produksi. Biaya bahan langsung adalah setiap bahan baku yang menjadi bagian yang tak terpisahkan dari produk jadi. Sebagai contoh, dalam membuat pakaian pria, kain merupakan bahan langsung. Biaya tenaga kerja langsung adalah gaji yang diperoleh pekerja yang mengubah bahan dari keadaan mentah menjadi produk jadi. Sebagai contoh, gaji yang dibayarkan kepada pekerja pabrik pakaian yang memotong kain dan menjahit hasil potongan tersebut adalah biaya tenaga kerja langsung. Terkadang biaya ini disebut sebagai overhead produksi (manufacturing overhead) atau beban pabrik (factory burden). Overhead pabrik mencakup semua biaya produksi selain bahan langsung dan tenaga kerja langsung. Penekanannya disini adalah pada istilah biaya produksi. Sebagai contoh, gaji pengendali persediaan adalah overhead pabrik.

Berdasarkan penentuan harga pokok yang benar dari suatu produk akan dapat mengurangi ketidakpastian dalam penentuan harga jual. Harga pokok produk biasanya terdiri dari dua jenis biaya yaitu biaya produksi dan biaya non produksi. Dalam penentuan harga pokok produk harus diperhatikan unsur-unsur biaya apa saja yang masuk dalam harga pokok produk dan mengalokasikan unsur-unsur biaya tersebut secara tepat sehingga dapat menggambarkan pengorbanan sumber ekonomi yang sesungguhnya. Menurut Armanto Witjaksono (2006 : 25) mengemukakan bahwa " Harga pokok produksi adalah tata cara atau metode penyajian informasi biaya produk dan jasa berdasarkan informasi dari sistem akuntansi biaya dan sistem biaya ".

Perhitungan harga pokok dilakuakan dengan menjumlahkan seluruh unsur biaya produksi, sedangkan harga pokok produksi per unit ditentukan dengan membagi seluruh seluruh total biaya produksi dengan volume produksi yang dihasilkan atau yang diharapkan akan dihasilkan. Cara seperti ini yang harus digunakan apabila berhubungan dengan prinsip akuntansi. Menurut Mulyadi (2010), metode penentuan harga pokok produksi merupakan cara untuk memasukkan unsur - unsur biaya ke dalam harga pokok produksi. Dalam penentuan harga pokok produksi dikenal dua metode pendekatan, yaitu pendekatan full costing dan variabel costing. Full Costing merupakan 
p-ISSN : 2599-1418

e-ISSN : 2599-1426

penentuan harga pokok produksi yang memperhitungkan semua unsur biaya produksi ke dalam harga pokok produksi, yang terdiri dari biaya bahan baku, biaya tenaga kerja langsung, dan biaya overhead pabrik baik yang berprilaku variabel maupun tetap. Sedangkan Variabel costing merupakan metode penentuan harga pokok produksi yang memperhitungkan biaya produksi yang berprilaku dalam harga pokok produksi yang terdiri dari bahan baku, biaya tenaga kerja langsung, dan biaya overhead pabrik variabel. Biaya yang berprilaku variabel dalam harga pokok produksi yang terdiri dari biaya bahan baku, biaya tenaga kerja langsung, dan biaya overhead pabrik variabel.

Metode Harga Pokok Penuh atau full costing adalah semua unsur biaya produksi diperhitungkan dalam penentuan harga pokok produksi, yaitu biaya bahan baku, biaya tenaga kerja langsung, biaya overhead pabrik. Sehingga harga pokok produksi menurut metode harga pokok penuh ini terdiri dari unsur biaya produksi sebagai berikut.

$\begin{array}{lc}\text { Biaya bahan baku langsung } & x x x x \\ \text { Biaya tenaga kerja langsung } & x x x x \\ \text { Biaya overhead pabrik tetap } & x x x x \\ \text { Biaya overhead pabrik variabel } & \frac{x x x x}{x x x x} \\ \text { Harga pokok produksi } & \end{array}$

Metode harga pokok variabel hanya memperhitungkan biaya produksi yang berprilaku variabel saja, baik untuk biaya bahan baku, biaya tenega kerja langsung, maupun biaya overhead pabrik. Dengan demikian menurut pendekatan ini harga pokok produksi terdiri dari unsur biaya produksi sebagai berikut.

$\begin{array}{lc}\text { Biaya bahan baku langsung } & x x x x \\ \text { Biaya tenaga kerja langsung } & x x x x \\ \text { Biaya overhead pabrik variabel } & \frac{x x x x}{x x x x} \\ \text { Harga pokok produksi } & \end{array}$

Jurnal Pendidikan Ekonomi Undiksha Volume 10 No. 1 Tahun 2018

Perbedaan antara konsep Variable Costing dengan Full Costing tersebut terletak pada tujuan utamanya yaitu, konsep variabel costing mempunyai tujuan utama untuk pelaporan internal sedangkan konsep full costing mempunyai tujuan utama untuk pelaporan eksternal. Adanya kedua perbedaan tersebut mengakibatkan perbedaan perlakuan terhadap biaya produksi tetap yang selanjutnya mempengaruhi, a) penentuan besarnya harga pokok produk dan besarnya harga pokok persediaan, b) penggolongan dan penyajian di dalam laporan laba-rugi (Eprilianta, 2011).

Menurut Mulyadi (2012), pada prinsipnya harga jual harus dapat menutupi biaya penuh ditambah dengan laba yang wajar. Harga jual sama dengan biaya produksi ditambah markup. Krismiaji dan Aryani (2011 : 325) menyatakan bahwa "Pendekatan umum dalam penentuan harga jual adalah menambahkan angka perkiraan laba (markup) pada harga pokok ". Markup adalah selisih anatar harga jual dan harga pokok produk. Markup biasanya berupa persentase tertentu dari harga pokok produk. Pendekatan ini disebut dengan cost-plus pricing karena persentase markup yang telah ditentukan dimuka ditambahkan pada angka harga pokok untuk menentukan harga jual. Cara menghitung dengan menggunakan markup yaitu. $\%$ Markup $=\frac{\text { BiayaNon ProduksitLabayang Diharapkan }}{\text { BiayaProduksi }}$

Dalam pendekatan full costing, taksiran biaya penuh yang dipakai sebagai dasar penentuan harga jual terdiri dari unsurunsur sebagai berikut.

Biaya produksi :

Taksiran bahan baku $\quad$ xxxx

Taksiran TKL $\quad$ xxxx

Biaya overhead tetap

Biaya overhead variabel $\quad \underline{x x x}$ $\pm$ 
p-ISSN : 2599-1418

e-ISSN : 2599-1426
Jurnal Pendidikan Ekonomi Undiksha Volume 10 No. 1 Tahun 2018
Total kos produksi

$x x x x$

Biaya komersial :

Biaya pemasaran

$x x x x$

Biaya administrasi dan umum

$\underline{X X X X}$

$\stackrel{ \pm}{\text { Taksiran biaya komersial }}$

$\stackrel{+}{T}$ aksiran biaya penuh

$\underline{\mathrm{XXXX}}$

$\mathrm{XXXX}$

Dalam pendekatan variabel costing, taksiran biaya penuh yang dipakai sebagai dasar penentuan harga jual terdiri dari unsur-unsur sebagai berikut.

Biaya variabel :

Biaya produksi variabel

$x x x x$

Biaya adm. dan umum variabel

$x x x x$

Biaya pemasaran variabel

$\underline{X X X X}$

$\pm$

Taksiran total biaya variabel

$\operatorname{XXXX}$

Biaya tetap :

Biaya produksi tetap

$X X X X$

Biaya administrasi dan umum tetap

Biaya pemasaran tetap

\begin{tabular}{l}
$X X X X$ \\
$X X X X$ \\
\hline
\end{tabular}

$\stackrel{ \pm}{T}$ aksiran total biaya tetap

$\underline{\mathrm{XXXX}}$

$\stackrel{+}{T}$ aksiran biaya penuh

$x x x x$

Pabrik tahu tempe Khoiriyah dalam menentukan perhitungan harga pokok produksi masih menggunakan metode yang sederhana karena masih ada biaya overhead pabrik yang belum diperhitungkan dalam penentuan harga pokok produksi seperti biaya air, listrik, bahan bakar, biaya transportasi, dan biaya penyusutan mesin. Beberapa elemen biaya yang sebenarnya masuk pada perhitungan harga pokok produksi sangat mempengaruhi besarnya laba yang didapat pabrik tahu tempe Khoiriyah. Hal ini terjadi karena tidak terperincinya dalam menghitung biaya produksi. Pabrik tahu tempe Khoiriyah belum sepenuhnya memperhatikan biaya overhead pabrik dan berfokus pada bahan baku kedelai dan biaya tenaga kerja saja. Sedangkan biayabiaya yang dikeluarkan pabrik tahu tempe
Khoiriyah tidak hanya biaya bahan baku kedelai dan biaya tenaga kerja saja, tetapi masih ada biaya overhead pabrik yang belum diperhitungkan.

Oleh karena itu, untuk memperkecil kesalahan yang terjadi dalam perhitungan harga pokok produksi dan menghasilkan harga jual yang tepat dan akurat diperlukan suatu metode yang baik. Metode yang tepat digunakan dalam pabrik tahu tempe Khoiriyah untuk menghitung harga pokok produksi adalah metode full costing. Peneliti memilih menggunakan metode full costing karena dalam metode ini memperhitungkan biaya tetap yang dianggap melekat pada harga pokok persediaan baik barang jadi maupun persediaan barang dalam proses yang belum terjual dan dianggap harga pokok penjualan jika produk tersebut sudah habis dijual. Dengan demikian maka perusahaan akan memperoleh biaya yang akurat serta dapat menetapkan harga jual yang lebih kompetitif. Dengan menerapkan metode ini diharapkan akan membantu pabrik tersebut khususnya pada pihak pabrik tahu Khoiriyah dalam penentuan harga pokok produksi dan harga jual dapat berfungsi lebih optimal, efektif, dan efisien. Serta penetapan harga jual yang tepat dan akurat untuk mencapai penetapan harga yang sewajarnya.

\section{METODE PENELITIAN}

Jenis penelitian ini merupakan penelitian deskriptif dengan menggunakan pendekatan kuantitatif. Adapun tujuan dari penelitian ini adalah untuk menganalisis penentuan harga pokok produksi dan harga jual tahu tempe dengan menggunakan metode full costing pada home industry Khoiriyah di Taman Sari, dan melakukan perbandingan antara perhitungan dengan menggunakan metode full costing yang dilakukan peneliti dengan perhitungan yang dilakukan oleh Home Industri Khoiriyah di Taman Sari, Singraja. 
p-ISSN : 2599-1418

e-ISSN : 2599-1426
Jurnal Pendidikan Ekonomi Undiksha

Volume 10 No. 1 Tahun 2018
Lokasi penelitian ini dilaksanakan di home industry tahu tempe Khoiriyah yang beralamat di jalan Pulau Selayar, gang VI No 14 , Singaraja, Buleleng, Bali. Data dikumpulkan dengan menggunakan metode dokumentasi dan data dianalisis menggunakan metode full costing untuk menentukan harga pokok produksi dan harga jual.

Jenis data yang digunakan dalam penelitian ini adalah data kuantitatiif. Data Kuantitatif adalah data yang dapat diukur satuannya dan biasanya berupa angkaangka. Data kuantitatif dalam penelitian ini adalah data berupa biaya - biaya mendukung dalam melakukan perhitungan harga pokok produksi dan hasil perhitungan harga pokok produksi dan harga jual produk tahu tempe dengan menggunaka metode full costing yang dilakukan oleh peneliti

Sumber data dalam penelitian ini adalah primer berupa data dari hasil dokumentasi dan wawancara dengan melakukan pencatatan data - data mengenai biaya produksi, hasil produksi, proses produksi, dan data lainnya yang berkaitan dengan penelitian pada home industry tahu tempe Khoiriyah.

Metode yang digunakan dalam penelitian ini yaitu dengan metode metode wawancara dan dokumentasi untuk memperoleh keterangan-keterangan yang berkaitan dengan permasalahan yang ada di dalam penelitian ini. Dalam penelitian ini wawancara digunakan dengan pedoman wawancara tidak terstruktur yang bertujuan untuk memperoleh data mengenai harga pokok produksi dan harga jual pada home industry "Khoiriyah" Metode dokumentasi dengan melakukan pencatatan terhadap data-data mengenai biaya produksi, hasil produksi, proses produksi, dan data lainnya yang berkaitan dengan penelitian pada home industry tahu tempe "Khoiriyah".

Teknik analisis data yang digunakan adalah analisis deskriptif. Adapun langkah - langkah yang dilakukan untuk menjawab rumusan masalah adalah mendeskripsikan perhitungan harga pokok produksi perusahaan dengan menjabarkan biaya - biaya produksi yang dikeluarkan oleh perusahaan dalam suatu periode tertentu. Menurut Mulyadi (2010) menentukan prosedur penentuan harga pokok dengan menggunakan metode full costing, dengan cara mengumpulkan data produksi dalam periode tertentu dan mengumpulkan biaya bahan, biaya tenaga kerja, dan biaya overhead pabrik periode tertentu untuk menyusun laporan produksi dan menghitung produksi ekuivalen dalam rangka menghitung harga pokok satuan, mendeskripsikan dan melakukan penghitungan harga pokok produksi sesuai metode full costing, membandingkan prosedur penghitungan harga pokok produksi dari kajian teori dengan

prosedur

perusahaan.mendeskripsikan

penghitungan harga jual menurut perusahaan berdasarkan data yang diperoleh seperti biaya non produksi dan persentase laba yang digunankan oleh perusahaan. Menurut Krismiaji dan dan aryani (2011) menentukan prosedur penentuan harga jual menurut metode cost plus pricing dengan cara mengumpulkan data produksi dan non produksi dalam periode tertentu, mendeskripsikan dan melakukan penghitungan harga jual sesuai metode cost plus pricing, menghitung harga satuan setiap elemen biaya, yaitu jumlah elemen biaya tertentu dibagi produksi ekuivalen dari elemen biaya tersebut, kemudian membandingkan penghitungan harga jual menurut perusahaan dengan metode cost plus pricing yang dilakukan oleh peneliti.

\section{HASIL PENELITIAN DAN PEMBAHASAN}

\section{Hasil Penelitian}

Perhitungan biaya produksi dalam menentukan harga pokok yang dilakukan 
p-ISSN : 2599-1418

e-ISSN : 2599-1426
Jurnal Pendidikan Ekonomi Undiksha Volume 10 No. 1 Tahun 2018 oleh perusahaan hanya berdasarkan perkiraan saja. Selama bulan Juni home industry Khoiriyah memproduksi 2.310 kilogram kacang kedelai yang menghasilkan 840 ember tahu. Satu cetakan tahu menghasilkan 121 potong tahu, satu cetakan tahu membutuhkan $2,75 \mathrm{~kg}$ kacang kedelai. Sedangkan dalam memproduksi tempe dalam bulan Juni memerlukan $3.600 \mathrm{~kg}$ kacang kedelai. Setiap harinya perusahaan memproduksi $120 \mathrm{~kg}$ kacang kedelai menghasilkan 100 pcs tempe. Jadi dalam sebulan home industry Khoiriyah menghasilkan 3.000 pcs tempe.

Dalam bulan Juni home industry Khoiriyah memproduksi $5.910 \mathrm{~kg}$ kacang kedelai yang menghasilkan 840 ember tahu dan 3.000 pcs tempe. Sedangkan untuk biaya tenaga kerja langsug dihitung berdasarkan jumlah kedelai yang diproduksi per hari. Untuk memproduksi $5,5 \mathrm{~kg}$ kacang kedelai menjadi tahu, digaji Rp. 10.000. sedangkan memproduksi $120 \mathrm{~kg}$ tempe digaji $\mathrm{Rp} 80.000$. Jadi selama bulan Juni home industry Khoiriyah mengeluarkan biaya tenaga kerja langsung sebesar Rp. 6.600.000. Biaya listrik yang dikeluarkan oleh perusahaan selama bulan Juni 2017 adalah Rp. 200.000, biaya kayu serutan Rp. 2.760.000. Perhitungan harga pokok yang dilakukan perusahaan adalah untuk tahu Rp. 27.503,571 dan tempe Rp. 9.223 yang diperoleh dari total biaya dibagi jumlah produksi.

Tabel 1. Perbandingan antara Perhitungan Harga Pokok Produksi dengan Metode Full Costing dan Metode Perusahaan.

Keterangan $\quad$ Metode full costing Metode perusahaan Selisih (Rp)

(Rp)

(Rp)

\begin{tabular}{lccc}
\hline Tahu & $28.618,228$ & $27.503,571$ & $1.114,657$ \\
Tempe & $9.610,437$ & 9.223 & 387,437 \\
\hline
\end{tabular}

Perbandingan hasil perhitungan harga pokok produksi dengan menggunakan cara perusahaan dan metode full costing diketahui bahwa selisih biaya produksi tahu adalah $\mathrm{Rp} 1.114,657$, dan selisih biaya produksi tempe adalah $\mathrm{Rp} 387,437$. Jumlah produksi tahu dalam satu bulan sebanyak 840 ember jadi selisih biaya produksi tahu selama bulan Juni adalah $\mathrm{Rp} 33.439,71$ sedangkan untuk jumlah produksi tempe selama satu bulan sebanyak 3.000 pcs, jadi selisih biaya produksi tempe selama bulan Juni adalah $\mathrm{Rp} 11.623,11$. Jadi total selisih biaya produksi tahu dan teme dengan metode perusahaan dan metode full costing selama bulan Juni 2017 adalah Rp45.062. Diketahui bahwa perhitungan harga pokok produksi dengan metode perusahaan dan metode full costing memiliki perbedaan.
Pada perhitungan harga pokok produksi dengan metode full costing harga pokok produksi yang dihasilkan lebih besar dibandingkan dengan perhitungan harga pokok produksi dengan metode perusahaan. Hal ini karena dengen menggunakan metode full costing semua biaya dirinci secara jelas, baik itu biaya bahan baku, tenaga kerja langsung, dan biaya overhead pabrik sedangkan pada perhitungan harga pokok produksi dengan metode yang digunakan perusahaan harga pokok produksi yang dihasilkan lebih kecil karena perusahaan tidak memasukkan biaya overhead pabrik secara rinci ke dalam biaya produksinya. Perusahaan hanya merinci biaya bahan baku langsung, biaya tenaga kerja langsung dan biaya overhead namum biaya overhead yang dihitung pada 
p-ISSN : 2599-1418

e-ISSN : 2599-1426
Jurnal Pendidikan Ekonomi Undiksha Volume 10 No. 1 Tahun 2018 proses perhitungan biaya produksi yang dilakukan perusahaan hanya biaya listrik dan biaya sekam kayu. Untuk biaya penyusutan mesin, peralatan, dan bangunan, biaya pemeliharaan mesin dan peralatan, dan biaya kain tidak di bebankan oleh perusahaan oleh karena itu perhitungan biaya produksi dengan metode perusahaan lebih kecil dibandingkan dengan metode full costing.

Perhitungan harga jual tempe menurut cost plus pricing

Perhitungan harga jual tempe menurut metode cost plus pricing.

Perhitungan markup

Biaya transportasi

Biaya pemasaran

Laba yang diharapkan

Jumlah

600.000

0

$\frac{5.766 .262,383+}{6.366 .262,383}$

Biaya produksi

Markup (\%)

$28.831 .311,916$

$22 \%$

Perhitungan harga jual :

Biaya produksi

28.831.311,916

Markup (\% markup x biaya produksi)

$\underline{6.342 .888,621+}$
Jumlah

$35.174 .200,537$

Volume produk Harga jual per unit

\subsection{0}

$11.724,733$

b. Perhitungan harga jual tahu menurut cost plus pricing

Perhitungan harga jual tahu menurut metode cost plus pricing.

Perhitungan markup

Biaya transportasi

Biaya pemasaran

Laba yang diharapkan

Jumlah

600.000

$\underline{4.807 .862,338+}$ $5.407 .862,338$

Biaya produksi

Persentase markup (\%)

Perhitungan harga jual :

24.039.311,694 $22 \%$

Biaya produksi

24.039.311,691

(\% markup x b.produksi)

Jumlah

$\underline{5.288 .648,572+}$

$29.327 .960,263$

Volume produk

Harga jual per unit

Tabel 2. Perbandingan Perhitungan Harga Jual yang Ditetapkan Home Industry dengan Perhitungan Harga Jual dengan Pendekatan Cost Plus Pricing.

\begin{tabular}{ccc} 
& Pendekatan cost & Metode perusahaan \\
\hline Keterangan & plus pricing & Selisih (Rp)
\end{tabular}

Harga jual tempe

Harga jual tahu

Setelah melakukan perhitungan tersebut, dapat diketahui bahwa harga jual tempe dengan menggunakan cost plus pricing sebesar $\mathrm{Rp} 11.724,733$ dan tahu sebesar Rp 34.914,235. Jadi perbandingan harga jual yang ditetapkan oleh home industry Khoiriyah dengan perhitungan harga jual dengan metode cost plus pricing diketahui selisih dari harga jual tempe sebesar Rp. 1.724,733 dan selisih harga jual tahu sebesar Rp.
Rp. 10.000

Rp. 40.000
$1.724,733$

$5.085,765$

$5.085,765$. Diketahui bahwa perhitungan harga jual dengan metode perusahaan dan pendekatan cost plus pricing memiliki perbedaan. Pada perhitungan harga jual dengan pendekatan cost puls pricing harga jual yang diperoleh lebih besar dibandingkan dengan perhitungan harga jual yang ditetapkan oleh perusahaan pada produk tempe. Hal ini karena dengan menggunakan pendekatan cost plus pricing semua biaya dirinci secara jelas, 
p-ISSN : 2599-1418

e-ISSN : 2599-1426

baik itu biaya produksi dalam satu bulan, biaya tranportasi, laba yang diharapkan dan persentase markup sedangkan pada harga jual yang digunakan perusahaan harga jual yang dihasilkan lebih kecil karena perusahaan tidak menghitung persentase markup dan memasukkan biaya non produksi secara rinci dan biaya produksi. Namun selisih dari harga jual tahu dengan menggunakan pendekatan cost plus pricing lebih kecil dari harga jual yang ditetapkan oleh perusahaan. Perhitungan harga jual dengan pendekatan cost plus pricing sebesar Rp. $34.914,235$ sedangkan harga jual yang ditetapkan oleh perusahaan Rp. 40.000 . Jadi perusahaan memperoleh keuntungan lebih besar pada produk tahu dan menetapkan harga jual tahu sebesar Rp. 40.000 tidak akan merugikan perusahaan.

\section{PEMBAHASAN}

Berdasarkan hasil penelitian diatas, terdapat perbedaan pada.

1. Harga pokok produksi

Perhitungan biaya produksi yang dilakukan oleh perusahaan hanya berdasarkan perkiraan saja. Perusahaan hanya menghitung biaya produksi berdasarkan bahan baku dan biaya tenaga kerja saja tanpa menghitung biaya seperti penyusutan, dan biaya overhead pabrik. Hal ini dapat mempengaruhi keuntungan yang didapat oleh perusahaan dan dapat membuat perusahaan mengalami kerugian. Oleh sebab itu perusahaan harus melakukan perhitungan harga pokok produki secara tepat. Agar produksi yang dihasilkan dapat dijual dengan harga yang bersaing dan dengan kualitas yang bersaing juga. Selain itu agar dapat mengikuti perubahan dari harga kacang kedelai yang tidak stabil.

Harga pokok menurut taksiran perusahaan adalah sebesar Rp 9.223 untuk tempe dan $\mathrm{Rp} 27.503,571$ untuk tahu. Sedangkan harga pokok produksi
Jurnal Pendidikan Ekonomi Undiksha

Volume 10 No. 1 Tahun 2018 menurut metode full costing adalah sebesar Rp 9.610,473 untuk tempe dan Rp 28.618,228 untuk tahu. Perhitungan harga pokok produksi dengan metode perusahaan dan metode full costing memiliki perbedaan. Pada perhitungan harga pokok produksi dengan metode full costing harga pokok produksi yang dihasilkan lebih besar dibandingkan dengan perhitungan harga pokok produksi dengan metode perusahaan. $\mathrm{Hal}$ ini karena dengan menggunakan metode full costing semua biaya dirinci secara jelas, baik itu biaya bahan baku, tenaga kerja langsung, dan biaya overhead pabrik sedangkan pada perhitungan harga pokok produksi dengan metode yang digunakan perusahaan harga pokok produksi yang dihasilkan lebih kecil karena perusahaan tidak memasukkan biaya overhead pabrik secara rinci ke dalam biaya produksinya. Perusahaan hanya merinci biaya bahan baku langsung, biaya tenaga kerja langsung dan biaya overhead namum biaya overhead yang dihitung pada proses perhitungan biaya produksi yang dilakukan perusahaan hanya biaya listrik dan biaya sekam kayu. Untuk biaya penyusutan mesin, peralatan, dan bangunan, biaya pemeliharaan mesin dan peralatan, dan biaya kain tidak di bebankan oleh perusahaan oleh karena itu perhitungan biaya produksi dengan metode perusahaan lebih kecil dibandingkan dengan metode full costing.

Jika perusahaan menggunakan metode full costing dalam menghitung biaya produksinya maka perusahaan harus mengidentifikasi seluruh biaya yang digunakan dalam proses produksi, membedakan antara biaya variabel dengan biaya tetap, memisahkan biaya produksi dengan biaya non produksi, dan memperhitungkan biaya produksi selain biaya bahan baku, biaya tenaga kerja langsung, dan biaya overhead pabrik tetap dan biaya overhead pabrik variabel.

2. Harga jual 
p-ISSN : 2599-1418

e-ISSN : 2599-1426

Home industry Khoiriyah menetapkan harga jual berdasarkan perkiraan sehingga tidak ada persentase khusus yang ditetapkan perusahaan guna mencapai laba tertentu. Hasil perhitungan harga jual menurut perusahaan memiliki perbedaan dengan metode cost plus pricing. Harga jual menurut perusahaan untuk tempe $\mathrm{Rp} 10.000$ dan tahu $\mathrm{Rp}$ 40.000 sedangkan menurut cost plus pricing yang diperhitungkan oleh peneliti adalah $\mathrm{Rp} 11.724,733$ untuk tempe dan Rp 34.914,235 untuk tahu dengan asumsi persentase laba yang diharapkan adalah sebesar $20 \%$.

Perhitungan harga jual dengan metode perusahaan dan pendekatan cost plus pricing memiliki perbedaan. Diketahui selisih dari harga jual tempe sebesar Rp. 1.724,733 dan selisih harga jual tahu sebesar Rp. 5.085,765. Pada perhitungan harga jual dengan pendekatan cost puls pricing harga jual yang diperoleh lebih besar dibandingkan dengan perhitungan harga jual yang ditetapkan oleh perusahaan pada produk tempe. Hal ini karena dengan menggunakan pendekatan cost plus pricing semua biaya dirinci secara jelas, baik itu biaya produksi dalam satu bulan, biaya tranportasi, laba yang diharapkan dan persentase markup sedangkan pada harga jual yang digunakan perusahaan harga jual yang dihasilkan lebih kecil karena perusahaan tidak menghitung persentase markup dan memasukkan biaya non produksi secara rinci dan biaya produksi. Namun selisih dari harga jual tahu dengan menggunakan pendekatan cost plus pricing lebih kecil dari harga jual yang ditetapkan oleh perusahaan. Perhitungan harga jual dengan pendekatan cost plus pricing sebesar Rp. $34.914,235$ sedangkan harga jual yang ditetapkan oleh perusahaan Rp. 40.000 . Jadi perusahaan memperoleh keuntungan lebih besar pada produk tahu dan menetapkan harga jual tahu sebesar Rp.
Jurnal Pendidikan Ekonomi Undiksha

Volume 10 No. 1 Tahun 2018

40.000 tetap tidak akan merugikan perusahaan.

\section{SIMPULAN DAN SARAN}

\section{Simpulan}

Berdasarkan hasil penelitian dan pembahasan maka dapat disimpulkan sebagai berikut. Pertama, perhitungan harga pokok produksi yang dilakukan home industry Khoiriyah adalah sebesar Rp. 27.503,571 untuk tahu dan Rp. 9.223 untuk tempe. Hasil tersebut diperoleh dari total biaya dibagi jumlah produksi. Kedua, Perhitungan harga pokok produksi dengan menggunakan metode full costing adalah sebesar Rp. 28.618,228 untuk tahu dan harga pokok produksi tempe per pcs adalah Rp 9.610,437. Perhitungan harga jual dengan menggunakan cost plus

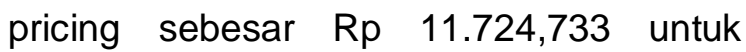
tempe dan Rp 34.914,235 untuk tahu. Ketiga, Hasil perhitungan harga pokok produksi dan harga jual menurut perusahaan memiliki perbedaan dengan perhitungan yang dilakukan oleh peniliti. Harga pokok menurut taksiran perusahaan adalah sebesar Rp 9.223 untuk tempe dan Rp 27.503,571 untuk tahu. Sedangkan harga pokok produksi menurut metode full costing adalah sebesar $\mathrm{Rp}$ 9.610,473 untuk tempe dan $\mathrm{Rp}$ 28.618,228 untuk tahu.. Pada perhitungan harga pokok produksi dengan metode full costing harga pokok produksi yang dihasilkan lebih besar dibandingkan dengan perhitungan harga pokok produksi dengan metode perusahaan. Harga jual menurut perusahaan untuk tempe $\mathrm{Rp} 10.000$ dan tahu Rp 40.000 sedangkan menurut cost plus pricing yang diperhitungkan oleh peneliti adalah $\mathrm{Rp} \quad 11.724,733$ untuk 
p-ISSN : 2599-1418

e-ISSN : 2599-1426

tempe dan $\mathrm{Rp} 34.914,235$ untuk tahu dengan asumsi persentase laba yang diharapkan adalah sebesar $20 \%$.

\section{Saran}

Berdasarkan simpulan di atas, maka dapat dikemukakan saran sebagai berikut. Pertama bagi home industry Khoiriyah, untuk dimasa yang akan datang, perusahaan sebaiknya melakukan perhitungan harga pokok produksi, sehingga biaya dari produksi dapat diketahui dengan tepat dan benar. Dengan perhitungan harga pokok maka harga jual dapat ditentukan dengan tepat sehingga perusahaan tidak mengalami kerugian dan tidak keliru dalam menetapkan harga jual, selanjutnya penyesuaian terhadap perubahan harga kacang kedelai dan keuntungan perusahaan dapat diketahui, karena kesalahan dalam menghitung harga pokok mengakibatkan kesalahan dalam menetukan harga jual produksi. Kedua, untuk kedepannya perusahaan harus lebih memperhatikan dalam melakukan perhitungan biaya produksi, misalnya lebih berhati-hati dan teliti dalam memasukkan biaya-biaya pada perhitungan harga pokok produksi. Karena kesalahan dalam perhitungan harga pokok produksi, bisa berpengaruh pada harga jual produk, sedangkan harga jual menentukan pendapatan dari perusahaan. Pendapatan ini berkaitan dengan kelangsungan hidup perusahaan tersebut. Ketiga, selain mempertahankan kualitas dari produknya, home industri tahu dan tempe Khoiriyah sebaiknya juga memperhatikan masalah penetapan harga, agar konsumen tetap tertarik untuk membeli produk yang dipasarkan dan mampu bersaing dengan kompetitor di
Jurnal Pendidikan Ekonomi Undiksha Volume 10 No. 1 Tahun 2018

pasar, perusahaan sebaiknya memperhitungkan laba yang diharapkan berdasarkan jumlah unit yang diproduksi. Apabila unit yang diproduksi banyak maka laba yang didapat semakin banyak sehingga baik untuk rencana jangka pendek maupun rencana jangka panjang yang ingin dicapai dapat diketahui. Sehingga perusahaan dapat berkembang lebih besar lagi baik dalam segi produksi maupun dalam segi pemasaran, dan bersaing dengan produk sejenis yang dihasilkan perusahaan lain yang melakukan perhitungan harga pokok produksi dan penetapan harga jual secara lebih akurat. Kemudian bagi Akademik, bagi peneliti selanjutnya yang ingin melakukan penelitian penentuan harga pokok produksi dan harga jual, hendaknya lebih memasukkan aspek biaya-biaya yang lebih banyak. Karena semakin banyaknya aspek pembiayaan yang diperhitungkan, maka hasil perhitungan harga pokok produksinya semakin tepat.

\section{DAFTAR PUSTAKA}

Akuntansi Manajemen. Edisi 2. Yogyakarta: UPP STIM YKPN.

Bustami Bastian \& Nurlela. 2010, Akuntansi Biaya, Yogyakarta; Graha IImu.

Eprilianta, Silvania. 2011. "Analisis Perhitungan Harga Pokok Produksi Tahu Dengan Metode Full Costing Pada Industri Kecil (Studi Kasus CV Laksa Mandiri)". Tugas akhir. (tidak diterbitkan). Jurusan Ekonomi. Fakultas Ekonomi dan Bisnis.

Mulyadi. 1999. Akuntansi Biaya. Edisi Kelima, Cetakan Kelima. 
Yogyakarta: Akademi Manajemen Perusahaan YKPN.

.......... 2010. Akuntansi Biaya, Edisi Kelima, Cetakan ketujuh. Yogyakarta : Akademi Manajemen Perusahaan YKPN.
.........., 2005, Akuntansi Biaya, Edisi Kelima, Cetakan Ketujuh. Yogyakarta: Akademi Manajemen Perusahaan YKPN.

Samryn, L.M. 2012. Akuntansi Manajemen. Jakarta: Penerbit Kencana.

Supriyono. 2000. Akuntansi Biaya Pengumpulan Biaya dan Harga Pokok. Edisi Pertama. Yogyakarta: BPFE.
...... 2002. Manajemen Biaya Suatu Reformasi Pengelolaan Bisnis. Yogyakarta: BPFE.

Witjaksono, Armanto. 2006, Akuntansi Biaya, Jakarta: Graha IImu. 